\title{
NEW FLEA (SIPHONAPTERA) RECORD FOR HEERMANN’S KANGAROO RAT (DIPODOMYS HEERMANNI), SAN LUIS OBISPO COUNTY, CALIFORNIA
}

\author{
Howard O. Clark Jr. ${ }^{1}$ and Helen K. Pigage ${ }^{2}$
}

\begin{abstract}
Three Heermann's kangaroo rats (Dipodomys heermanni LeConte 1853) from San Luis Obispo County, California, were examined for ectoparasites. Two species of fleas were found, Meringis cummingi (C. Fox 1926) and Hoplopsyllus anomalus (Baker 1904). While M. cummingi has been reported frequently from this host (Dorman 1969, Eads et al. 1987), occurrence of H. anomalus on D. heermanni has not been reported before and represents a new host record.
\end{abstract}

Resumen.-Las ratas del canguro de tres Heermann (Dipodomys heermanni LeConte 1853), de San Luis Obispo County, California, fueron examinados por ectoparásitos. Se encontraron dos especies de pulgas, Meringis cummingi (C. Fox 1926) y Hoplopsyllus anomalus (Baker 1904). Mientras que M. cummingi ha informado con frecuencia de esta acogida (Dorman 1969, Eads et al. 1987), la aparición de H. anomalus en D. heermanni no se ha informado antes, y representa un nuevo registro de host.

Heermann's kangaroo rat (Dipodomys heermanni LeConte 1853) is endemic to California and typically occurs in arid and semiarid habitats within the central portion of the state (Kelt 1988). Dipodomys heermanni includes 8 recognized subspecies, one of which, $D$. $h$. morroensis, is listed as state and federally endangered (California Department of Fish and Game 2011).

Previous studies have identified 6 species of fleas occurring on D. heermanni: Aetheca wagneri (Baker 1904), Malaraeus telchinus (Rothschild 1905), Thrassis aridus (Prince 1944), Meringis cummingi (C. Fox 1926), and Meringis parkeri (Jordan 1937) (Coultrip et al. 1973, Hardy et al. 1974, Eads et al. 1987). In addition, Stark (1957) reported Thrassis arcuatus from D. h. jolonensis, Monterey County, California. Here we report a new flea record from D. heermanni.

On 1 April 2013, one trapping grid was established on private land within the Carrizo Plain National Monument, San Luis Obispo County, California (Township 11 North, Range 25 West, Section 20; elevation $787 \mathrm{~m}$ ). Thirty Sherman live traps $(7.5 \times 9.5 \times 30.5 \mathrm{~cm}$; H.B. Sherman Traps, Tallahassee, FL) were deployed, baited with white proso millet, and provisioned with an unbleached paper towel. Traps were set shortly before sunset and closed 3-4 hours later when captured animals were processed. Fleas collected from kangaroo rats were preserved in 70\% isopropyl alcohol. Following data and flea collection, captured rodents were released at the trap site. The fleas were dehydrated using standard methods, mounted on slides in Canada balsam, identified to species using published keys (Hubbard 1947, Eads et al. 1987), and deposited at the Denver Museum of Nature \& Science (2001 Colorado Boulevard, Denver, CO 80205).

Three adult Heermann's kangaroo rats (subspecies D. h. swarthi; Kelt 1988) were captured ( 1 female and 2 males) from which 4 fleas were collected. Three of the fleas were identified as Hoplopsyllus anomalus (Baker 1904) (2 males, accession numbers ZE.45283 and ZE.45284; 1 female, ZE.45286) and one flea, a male, was identified as Meringis cummingi (C. Fox 1926; accession number ZE.45282). The $H$. anomalus represents a new record for the Heermann's kangaroo rat. Meringis cummingi is commonly associated with Dipodomys heermanni; however, $H$. anomalus is commonly associated with sciurids. On the Carrizo Plain, kangaroo rats have largely filled the sciurid niche, usually filled by Otospermophilus beecheyi (Richardson 1859) (Tabor et al. 1993). No O. beecheyi were captured in work done at the Carrizo Plain National Monument trap site (H.O. Clark Jr. unpublished data). We know, however, that both $D$. ingens (Merriam

1Garcia and Associates, 993 Ezie Avenue, Clovis, CA 93611. E-mail: hclark@garciaandassociates.com

${ }^{2}$ University of Colorado, Colorado Springs, 1420 Austin Bluffs Parkway, Colorado Springs, CO 80918. 
1904) and D. h. swarthi (Kelt 1988) share ectoparasites, as we have reported H. anomalus from both species. The single specimen of Meringis sp. collected previously by us (Clark et al. 2014) was a female whose identity to species could not be determined (Eads et al. 1987). Based on the collection of a male from the same site, we think that it was most likely M. cummingi. The observed flea intensity was 1.33, however, this low value was not surprising, as other authors (Kelt 1988) have reported relatively low flea intensities $(0.04-0.86)$ on $D$. heermanni. Hubbard (1961) reported M. cummingi taken from $D$. heermanni at flea intensities of 2.0-8.0, depending on collection site and time of year. Tabor et al. (1993) reported the mean number of fleas on $67 \mathrm{D}$. ingens as 4.34 .

Fleas and other parasites can potentially adversely affect their hosts (Clark et al. 2006); however, our examination of kangaroo rats with fleas during this study revealed no unhealthy or weakened individuals. Further research is needed to determine how kangaroo rats manage flea loads (e.g., by dust-bathing) and what effects fleas have on kangaroo rat populations, if any.

We thank SunPower ${ }^{\circledR}$ Corporation, Inc., for providing support for this study. We thank S.I. Hagen and 2 anonymous reviewers for improving the manuscript. We thank J. Stephenson, collections manager at the Denver $\mathrm{Mu}$ seum of Nature \& Science, for specimen accession and O.R. Larson at the University of North Dakota for verification of flea identification. Kangaroo rats were handled and processed under the authority of federal permit TE797267-16, a memorandum of understanding by and between H.T. Harvey \& Associates and the California Department of Fish and Wildlife (CDFW), and a CDFW-issued scientific collecting permit (SCP 003366).

\section{Literature Cited}

California Department of Fish and Game. 2011. Special animals (898 taxa). California Department of Fish and Game, Biogeographic Data Branch, California Natural Diversity Database, Sacramento, CA.

Clark, H.O., Jr., H.K. Pigage, C.A. Wilkinson, and R.K. BurTon. 2014. Ectoparasites on the giant kangaroo rat, Carrizo Plain National Monument, San Luis Opispo County, California. Western Wildlife 1:8-11.

Clark, H.O., Jr., H.S. Shellhammer, and S.D. Gaimari. 2006. Ectoparasites found on salt marsh harvest mice in the northern salt marshes of Grizzly Bay, California. California Fish and Game 92:52-54.

Coultrip, R.L., R.W. Emmons, L.J. Legters, J.D. MarSHaLl JR., AND K.F. Murray. 1973. Survey for the arthropod vectors and mammalian hosts of Rocky Mountain spotted fever and plague at Fort Ord, California. Journal of Medical Entomology 3:303-309.

Dorman, D.E. 1969. New host and distribution records for species of Meringis (Siphonaptera, Hystrichopsyllidae). Journal of Parasitology 55:1233.

Eads, R.B., E.O. Campos, and G.O. Maupin. 1987. A review of the genus Meringis (Siphonaptera: Hystrichopsyllidae). Journal of Medical Entomology 24:467-476.

Hardy, J.L., W.C. Reeves, R.P. Scrivani, and D.R. RoBERTs. 1974. Wild mammals as hosts of Group A and Group B arboviruses in Kern County, California. American Journal of Tropical Medicine and Hygiene 23:1165-1177.

Hubbard, C.A. 1947. Fleas of western North America: their relation to the public health. Iowa State College Press, Ames, IA. 533 pp.

1961. Fleas from the kangaroo rats of northern California. Entomological News 72:133-139.

Kelt, D.A. 1988. Dipodomys heermanni. Mammalian Species 323:1-7.

Merriam, C.H. 1904. New and little known kangaroo rats of the genus Perodipus. Proceedings of the Biological Society of Washington 17:139-145.

STARK, H.E. 1957. Five new fleas of the genus Thrassis Jordan, 1929 (Ceratophyllidae: Siphonaptera), a genus of known importance in plague transmission. Journal of Parasitology 43:332-346.

Tabor, S.P., D.F. Williams, D.J. Germano, and R.E. Thomas. 1993. Fleas (Siphonaptera) infesting giant kangaroo rats (Dipodomys ingens) on the Elkhorn and Carrizo Plains, San Luis Obispo County, California. Journal of Medical Entomology 30:291-294.

Received 6 February 2014 Accepted 29 September 2014 